\title{
Construction of an educational booklet for elderly hypertensive patients: nursing contributions
}

Yara de Oliveira Sampaio1, Marcília Cavalcante Araújo1, Jéssica Daniele Cardozo Queiroz', Natasha Marques Frota', Bruna Michelle Belém Leite Brasil'1, Rosiléa Alves de Sousa', Débora de Araújo Moreira Varela', Samila Torquato Araújo', Lívia Moreira Barros $^{2}$, Joselany Áfio Caetano², Francisco Gilberto Fernandes Pereira ${ }^{3}$

\section{Abstract}

Objective: To develop an educational booklet for elderly hypertensive patients.

Method: A Methodological study to building an educational booklet with guidance on control and management of High Blood Pressure facing the elderly. The construction of the booklet took place between September and October 2015 and took place in two stages: literature; and the manufacture of printed educational technology.

Results: The booklet entitled "Knowing better Hypertension" was contextualized with easy to understand information composed of 15 illustrated pages and organized in a way which covers the main approaches to high pressure, dynamic and self-explanatory way, to leave clearer and to understand for the aged.

Conclusion: The main purpose of the construction of this booklet was to increase the potential of the elderly to promote their health, and ensure a better understanding of the issues surrounding hypertension.

\section{Introduction}

Aging is a condition of the world today. However, for a healthy aging, the population requires strategies that seek quality of life $(\mathrm{QOL})$. The elderly population has some factors that make them vulnerable to illness, added to this, misinformation about ways of prevention and disease control constitutes a major health risk.

The Noncommunicable Chronic Diseases (NCDs) have become a major public health challenge, aimed at reducing the impact of these
1 Department of Nursing, Centro Universitário Estácio. Fortaleza, Brazil

2 Department of Nursing, University Federal of Ceará. Fortaleza, Brazil

3 Department of Nursing, University Federal of Piauí. Teresina, Brazil

\section{Contact information:}

Natasha Marques Frota

झ natashafrota_@hotmail.com
Keywords
Educational Technology; Hypertension; Nursing; Education Nursing. 
diseases in general with the promotion of health, prevention and reduction of complications [1,2].

Among the NCDs, the systemic arterial hypertension $(\mathrm{SAH})$ remains the most frequent diseases and the main risk factor for cardiovascular disease. The prevalence of hypertension is increasing worldwide especially as a result of population aging, but also the sedentary lifestyle, inadequate food and the increase in overweight and obesity rates. For these reasons, preventive measures, early detection of these diseases and adequate therapeutic approach are essential [3].

The prevalence of hypertension in the elderly is high, and the correct diagnosis, and the persistence of patient monitoring are relevant to achieve an effective treatment. Adherence to treatment, including changes in lifestyle consists of a significant factor in achieving a healthy life [4].

One of the major challenges faced by health professionals is to find effective strategies to motivate and help people with chronic conditions, including those with hypertension, to modify their lifestyle and play an active role in their treatment [5].

The nurse as a health educator must guide the patient to the necessary care that can be done through the formation of alternative pedagogies in health education, highlighting the educational technologies. Thus, nurses can tailor their operations in the educational context to each and to facilitate the teaching-learning process, allowing them to participate in a moment of exchange of experiences [6].

Over the years, it is noticed the increased use of educational technologies by nurses in all areas of health care. Educational technologies arouse critical thinking of the people involved in the issues addressed by facilitating the process of teaching and learning, which provides skills development and mediating skills to care [7].
Faced with this reality, this measure becomes relevant to improve the quality of life of the elderly, as it facilitates and standardizes the guidelines to be carried out health care to individuals to understand better the process of health and illness and tread the ways of prevention as well as helping professionals during consultation with the elderly.

The elderly need health education by the senescence situation, but also by the gap of health-related knowledge, in particular, hypertension. Thus, the objective of this study was to build an educational booklet for elderly hypertensive patients.

\section{Methods}

This is a methodological research, focusing on the development, evaluation and improvement of an instrument or strategy that can improve a methodology [8]. An educational booklet with guidance on control and management of systemic hypertension facing elderly was developed.

The methodology of Escher [9], literature and preparation of educational materials were adopted. The construction of the booklet took place between September and October 2015, in which a search in major publications of the Ministry of Health of Brazil about the care and guidance on hypertension was carried out and the search for scientific articles to submit validation and clarity in its publication.

The literature used tools of databases: Scientific Electronic Library Online (Scielo); MEDLINE (Medical Literature Analysis and Retrieval Sistem online); Science Direct; and Lilacs (Latin American and Caribbean Health Sciences).

There were the different crossing of descriptors "hipertensão", "hypertension"; "technology educational", "educational technology"; "educação em enfermagem", "education nursing"; extracted from the DECS (Descriptor Health Sciences) portal of the Virtual Health Library (VHL). Inclusion criteria were 
full articles in English, Spanish, and Portuguese, and published in the period 2010 to 2015, which are related to the theme of hypertension. The exclusion criteria were related research reviews, dissertations, and theses. The final sample was 30 articles.

The built booklet was entitled: "Knowing better Hypertension", which addressed the care and guidelines on hypertension in its content. From the literature, the texts were drafted, seeking that were written clearly and succinctly to achieve accessible to all customers language.

Later a specialist in design was consulted to manufacture the attractive way of illustrations, easy to understand and consistent with the target audience. To complete the preparation of the material, there was a the support of a professional graphic designer in the area to run the graphical part of the booklet. The programs used were CorelDRAW Graphics Suite X7 and Adobe Photoshop to color the illustrations.

In the construction of the booklet, Moreira, Nobrega and Silva (2003), [10] assumptions were followed up that describe aspects related to language, illustration, and layout so that they are readable, understandable, effective and relevant.

The initial content of the booklet consists of attractive elements that seek to continue reading the educational material with the introductory theme approach. It will have the clarification of Hypertension: Causes, risk factors, symptoms, diagnosis, treatment and blood pressure measurement.

Illustrations that help explain and/or emphasize important points and ideas of the text were used, avoiding abstract illustrations and only decorative function in the text. The illustrations were arranged easily, to the reader follow them and understand them, next to the texts to which they refer.

The booklet layout had its source with number 14, as the material intended for adult /elderly audiences, being the source of the title two points higher than the text. Stylized and capital sources were not used enabling the reading. The colors were used with sensitivity and caution not to super colored, which would leave the visually polluted material. The print used was dull (paper and ink) on couches paper $60 \mathrm{~kg}$, reducing glare and improving readability.

\section{Results}

The titled booklet "Getting better Hypertension" was contextualized with easy to understand information composed of 15 illustrated pages and organized in a way which covers the main approaches to high pressure, dynamic and self-explanatory way, to leave more clear and understanding for the elderly.

The booklet was divided into nine fields, whose contents are described in Tables $\mathbf{1}$ and $\mathbf{2}$.

Preventable and not preventable SAH risk factors were available in the booklet as illustrative figures, so as to facilitate the understanding and comprehension of the elderly, as shown in Figure $\mathbf{1 .}$

In figure 2, it can be seen the control of hypertension through drug treatment.

After the presentation of care hypertensive with patient's lifestyle, vital parameters were added, which is made up of the values of blood pressure, blood glucose, weight and body mass index (BMI). The choice of these parameters was due to the need to control blood pressure and glucose levels, together with information on BMI, aiming to contribute to a possible diagnosis of $\mathrm{SAH}$.

In the last session of the booklet, there were added games titled as "Hunt-words" and "crossword," dynamically and to apply the knowledge gained in the booklet. The choice of games was due to the importance to program a playful activity. The educational game seeks to strengthen the ways to prevent the complications of hypertension, as well as control the blood pressure values of blood 
Table 1. Description of the contents concerning the areas Presentation Systemic Blood Pressure, Tips to measure blood pressure, hypertension and causes of hypertension.

\begin{tabular}{|c|c|}
\hline Domains & Descriptions of the content \\
\hline Presentation & $\begin{array}{l}\text { It aimed to contextualize about the vulnerability of the elderly in the illness, explain about the SAH and } \\
\text { the contribution of the booklet for hypertensives. This initial presentation is characterized as the door } \\
\text { for the elderly to enter into the booklet and try to draw attention in this regard to the information to be } \\
\text { presented in educational technology. }\end{array}$ \\
\hline $\begin{array}{l}\text { Systemic Blood } \\
\text { Pressure }\end{array}$ & $\begin{array}{l}\text { It discusses the physiology of blood pressure, also explaining the mechanism of systolic and diastolic } \\
\text { pressure. For a better understanding, the water pipes of a house were used as a sample, where pipes } \\
\text { would be our arteries and water would be the blood. In this domain, we tried to show how the } \\
\text { mechanism of blood pressure is but had to be careful not to use a scientific language to the elderly reach } \\
\text { an understanding and have knowledge that hypertension has no cure but can be controlled. }\end{array}$ \\
\hline $\begin{array}{l}\text { Tips for } \\
\text { measuring } \\
\text { blood pressure }\end{array}$ & $\begin{array}{l}\text { This domain reports that the blood pressure is not constant throughout the day, so they need to take } \\
\text { some care when it comes to measuring it, then, they are mentioned tips to be performed before and } \\
\text { at the time of measurement, as follows: rest } 5 \text { to } 10 \text { minutes in calm environment before making the } \\
\text { measurement, not exercising or physical effort in } 60 \text { to } 90 \text { minutes prior to measurement, do not drink } \\
\text { alcohol, caffeinated drinks and not smoking in the previous } 30 \text { minutes, empty the bladder, sit and keep } \\
\text { fit device on the arm, at heart, do not speak and do not cross the legs during measurement. In this area, } \\
\text { it was sought to define a more assertive way to be performing the diagnosis of hypertension, considering } \\
\text { that it is necessary to consider the completion of some sound practices before being gauging blood } \\
\text { pressure. }\end{array}$ \\
\hline Hypertension & $\begin{array}{l}\text { It stated that SAH is popularly known as high pressure, which causes an imbalance in the circulatory } \\
\text { system, increasing the pressure in the arteries. Moreover, the most aggravating of SAH is the reason of } \\
\text { having no cure. With the table, we emphasize the normal and abnormal blood pressure values. Given } \\
\text { that most of the elderly had no knowledge of the values obtained after the measurement of blood } \\
\text { pressure, detail identified the values found and how it is classified in its early and advanced stages, to } \\
\text { facilitate understanding of the elderly regarding a possible SAH diagnosis. }\end{array}$ \\
\hline $\begin{array}{l}\text { Hypertension } \\
\text { causes }\end{array}$ & $\begin{array}{l}\text { Not preventable risk factors: This domain aimed to portray not preventable risk factors for a future } \\
\text { diagnosis of SAH. They are family history, age, and gender. We sought to identify the situations that } \\
\text { increase the likelihood of hypertension, noting that while it may seem obvious risk does not mean sure, } \\
\text { but to be an unavoidable aggravating, there is no control for these factors. } \\
\text { Preventable risk factors were highlighted strategies that can prevent future hypertension. They were: } \\
\text { obesity and sensitivity to sodium, which again, in educations in health, relate the arteries to the water } \\
\text { pipes of a house, explaining that obesity can cause arteriosclerosis, like debris in the pipes, making the } \\
\text { passage of water from the house and the salt in the organism causes vasoconstriction also hindering the } \\
\text { movement; sedentary life, literally causing the disuse of functional systems; tobacco and alcohol because } \\
\text { they cause vasoconstriction; and stress, which if left untreated, can cause pressure spikes and keep it } \\
\text { high. Faced with comparisons about each risk factor, we seek to use a language easily understood to } \\
\text { be a better understanding of the main conditions and problems that increase the chances of a person } \\
\text { developing hypertension, and thus, identify the ways to prevent it. }\end{array}$ \\
\hline
\end{tabular}


Table 2. Description of the contents concerning the domains Symptoms, Diagnosis, Treatment and Complications of hypertension

\begin{tabular}{l|l} 
Domains & Description of content \\
\hline Symptoms & $\begin{array}{l}\text { SAH is a silent disease and if not treated properly can be attributed some symptoms when SAH is } \\
\text { already aggravated. Some are cited most prevalent symptoms, such as frequent urination, cramps, } \\
\text { chest pain, pain in the head, dizziness, tinnitus, weakness, blurred vision, and nosebleeds. In this topic, } \\
\text { we sought to show that the main symptoms that are related to hypertension, considering that the } \\
\text { symptoms reported are focused on the chronic form of the disease and the diseases brought by it and } \\
\text { not only serve as a basis for diagnosis. } \\
\text { It is explained how is the diagnosis of hypertension, which is made from blood pressure medication on } \\
\text { three different days with the minimum interval of one week. To supplement the information brought } \\
\text { in the previous section, we seek to bring the main form of diagnosis in this section, pointing out that } \\
\text { not only part of the onset of symptoms, as they may be linked to other diseases, and referencing the } \\
\text { practice of constant measurement as the main method for diagnosing hypertension. }\end{array}$ \\
Diagnosis & $\begin{array}{l}\text { Objetivamos identificar as principais complicações da HAS em alguns órgãos, que podem causar grande } \\
\text { prejuizo na vida diária dos afetados pela doença e causar impacto, para que percebam que prevenir-se é } \\
\text { a melhor maneira, já que é uma doença que não tem cura. } \\
\text { We aimed to identify the main complications of hypertension in some organs, which can cause great } \\
\text { damage in the daily life of the probands and impact, to realize that prevention is the best way since it is } \\
\text { a disease that has no cure. } \\
\text { This domain explains that the treatment of hypertension is customized according to the needs of each } \\
\text { person, and provides care for drug treatment and changes in lifestyle. This topic is shown the treatment } \\
\text { to be individual to each person, starting from the point that it is necessary to have specialized medical } \\
\text { care to reference the best form of treatment for each case and seek to take note of some important } \\
\text { points in the use of drug treatment, to obtain positive results in the control of hypertension. }\end{array}$ \\
\hline Treatment
\end{tabular}

Figure 1: Representation of non-preventable and preventable risk factors for hypertension.

\section{CAUSES OF HIYPERTENSION}

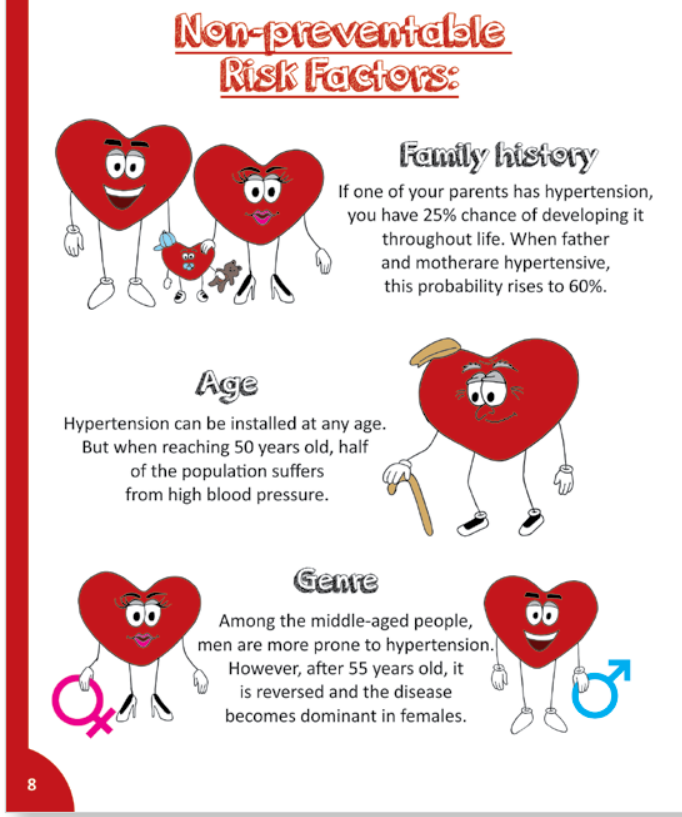

\section{Preventelole Rist} Fectors:

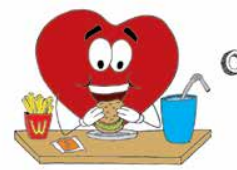

Obesify and won-healithy eating habits.

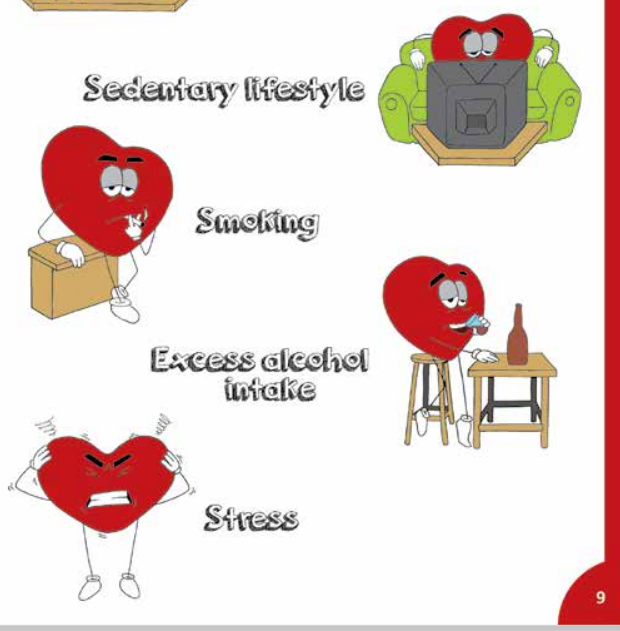


Figure 2: Treatment of hypertension.

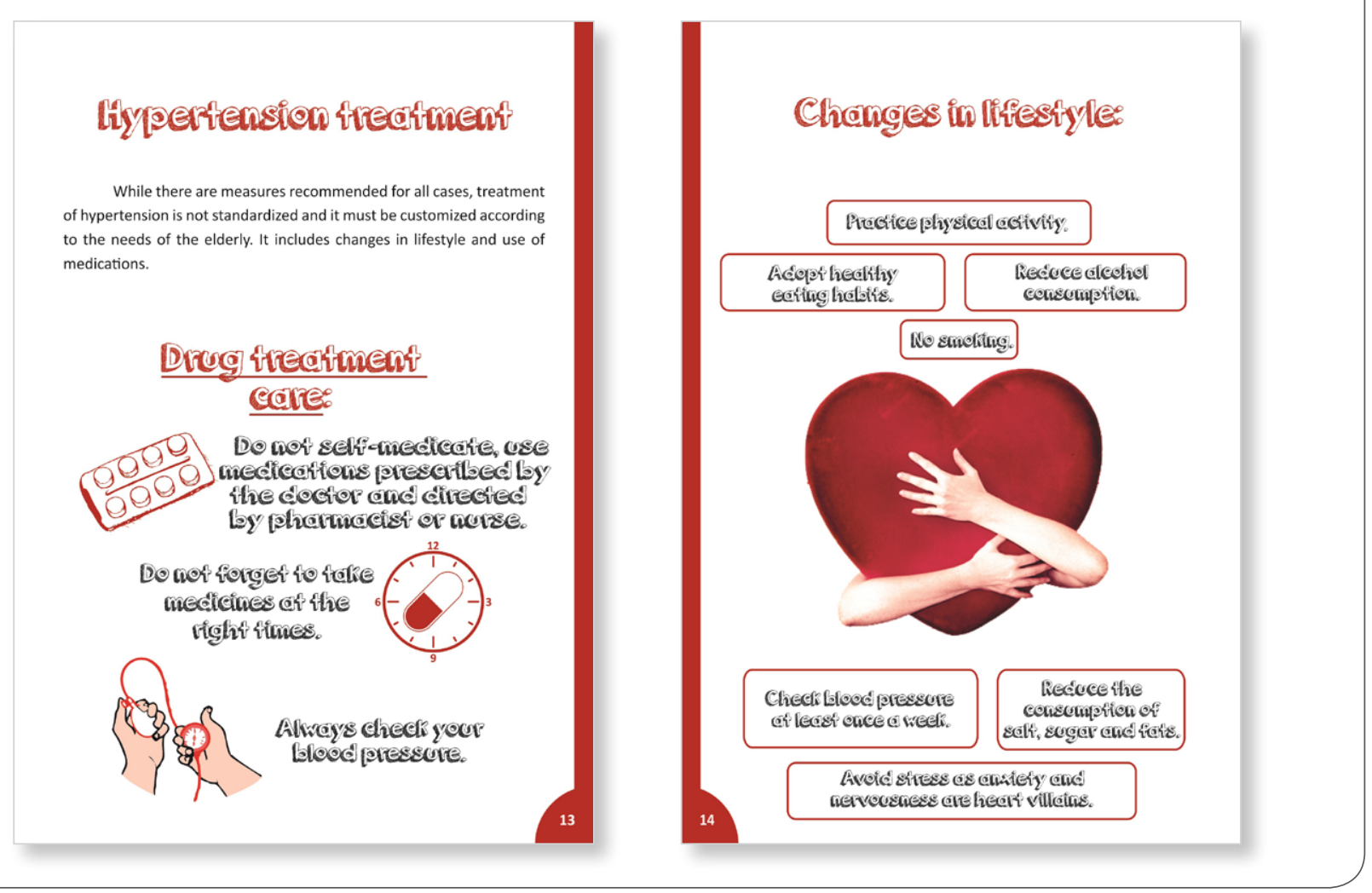

pressure. Besides that enable a way to stimulate the cognitive abilities of the elderly, it develops motor and reflective skills

\section{Discussion}

Health education in nursing was established as an important tool to be adopted as a means of integrating the patient care to improve understanding of certain information, facilitating learning and improving performance by creating technological resources. This facilitative tool has been widely addressed in research, not only for nurses but for other workers in the health sector, to represent a valuable resource for improving the quality of life [11].

Educational technologies can be used in different ways in different areas and with several objectives. In a study of the educational game on drugs for the blind, the findings showed that the evaluation by judges and by the target audience gave a reflection on the importance of producing a playful material to promote health education, which requires creativity and knowledge by nurses [12].

In another study, the authors built an educational game to acquire knowledge on blood pressure. The results showed that the use of educational technologies in the learning scenario awakens curiosity, motivation, and interest in learning about the target audience [13].

The use of educational technologies through digital media aims in the teaching-learning, digital inclusion. In a survey that used educational software aimed to the approach and the interaction of the elderly with the computer results showed that the use of educational technology is a great enabler tool for knowledge, because, with its use, the elderly were able to overcome the initial difficulties of computer use, which would be the use of the mouse and keyboard. However, they contributed the emotional and psychological well-being of the elderly, because they felt inserted in the today world [14]. 
The use of printed educational materials in the health field, such as care manuals, textbooks, brochures, and among others, promote positive and very significant results for participants of educations in health.

The results of the validation of an information booklet on the care for the elderly with dementia show that it is important to adopt technologies, incorporating new teaching methods. According to the author, the activities developed through educational technologies as the booklet can attend a health education based on actions that recognize the true needs, desires and aspirations of family/ caregivers [15].

In another state, the booklet is presented as a gerontology-technology able to facilitate understanding of the elder stoma and the family, being used as more of a health promotion tool, facilitator of the educational process in health, which makes the elder with a stoma co-participant in their care. The authors note in the study the relevance of the booklet, to be an instrument that recursively articulates the technical issues with human beings to humanize the nursing care [16].

Several studies show positive experiences in the use of educational technologies in the field of nursing, as a subsidy for the construction of various materials in this connection. Concerning the health of the elderly, the construction of this type of technology helps conduct self-care and actions promoting health.

In this study, we presented the educational booklet as a possible technology strategy to be used by nursing in their educational practice. The booklet aims to subsidize a resource to clarify SAH by a clear and objective language the elderly hypertensive patients and their family.

\section{Conclusions}

The main purpose of the construction of this booklet was to increase the potential of the elderlies to promote their health, and ensure a better un- derstanding of the issues surrounding hypertension. Through this, there is the importance of educational technology for nursing care, because the materials technology streamline health education activities and enable new teaching methods.

Thus, it is clear that the nurse is a professional who needs to enter into health promotion activities to increase the resoluteness of the population's needs through new teaching technologies that provide a better understanding of the topics covered, and the booklet as one tool to assist in this process.

A limitation of this study, we have not validation to experts, but it is expected that at an opportune time as possible to submit it to this validation, as well as apply to the target audience to carry out necessary adjustments and updates through scientific and technological advancement.

The study is not conclusive as to ensure that all information provided in the booklet are the essential information. A next step of the study will require the validation of this information from the experts in the field of nursing and technical designer.

\section{References}

1. Duncan BB, Chor D, Aquino EML, Bensenor IM, Mill JG, Schmidt $\mathrm{MI}$, et al. Chronic non-communicable diseases in Brazil: priorities for disease management and research. Rev Saúde Pública. [Internet] 2012 [cited 2015 nov 04]; 46:126-34. Available from: http://www.scielo.br/pdf/rsp/v46s1/17.pdf

2. Visentin A, Mantovani MF, Caveião C, Mendes TA, Neves AS, Hey AP. Quality of life of an institution hypertensive older women long stay. Rev Rene. [Internet] 2015 [cited 2015 nov 04]; 16:218-5. Available from: http://www.revistarene.ufc.br/revista/ index.php/revista/article/view/1921/pdf

3. Moraes NS, Souza JAG, Miranda RD. Hipertensão arterial, diabetes mellitus e síndrome metabólica: do conceito à terapêutica. Rev Bras Hipertensão [Internet] 2013 [cited 2015 nov 04]; 20:109-6. Available from: http://departamentos. cardiol.br/sbc-dha/profissional/revista/20-3.pdf

4. Barbosa RGB. treatment adherence and blood pressure control in older individuals with hypertension. Arq Bras Cardiol. [Internet] 2012 [cited 2015 dec 13]; 99:636-41. Available from: http://www.scielo.br/pdf/abc/v99n1/en_aop05112.pdf

5. Silva AM, Faria DS, Duarte GGM, Veiga EV, Silva PCS. Avaliação da depressão e do estilo de vida de idosos hipertensos. Rev Eletr Enferm. [Internet] 2013 [cited 2015 dec 13]; 2:368-74. Available 
from: https://www.fen.ufg.br/revista/v15/n2/pdf/v15n2a08.pdf

6. Valente JA. A comunicação e a educação baseada no uso das tecnologias digitais de informação e comunicação. Rev Unifeso Hum Soc. [Internet] 2014 [citado 2015 nov 04]; 1:141-66. Available from: http://revistasunifeso.filoinfo.net/index.php/ revistaunifesohumanasesociais/article/view/17/24

7. Áfio ACE, Balbino AC, Alves MDS, Carvalho LV. Analysis of the concept of nursing educational technology applied to the patient. Rev Rene. [Internet] 2014 [cited 2015 dec 13]; 15:15865. Available from: http://www.revistarene.ufc.br/revista/index. php/revista/article/view/1417/pdf_1

8. Polit DF, Beck CT. Fundamentos de pesquisa em enfermagem: avaliação de evidências para a prática da enfermagem. Porto Alegre: Artmed; 2011.

9. Echer IC. Elaboração de manuais de orientação para o cuidado em saúde. Rev Latino-Am Enfermagem [Internet] 2005 [cited 2015 dec 13]; 13:754-7. Available from: http://www.scielo.br/ pdf/rlae/v13n5/v13n5a22.pdf

10. Moreira MF, Nóbrega MML, Silva MIT. Comunicação escrita: contribuição para a elaboração de material educativo em saúde. Revista Brasileira de Enfermagem. [Internet] 2003 [cited 2015 dec 15]; 56: 184-88. Available from: http://www.scielo.br/ pdf/reben/v56n2/a15v56n2.pdf

11. Oliveira SRG, Wendhausen ALP. (Re)significando a educação em saúde: dificuldades e possibilidades da estratégia saúde da família. Trab Educ Saúde [Internet] 2014 [cited 2015 dec 13]; 12:129-47. Available from: http://www.scielo.br/pdf/tes/ v12n1/08.pdf

12. Mariano MR, Rebouças CBA, Pagliuca LMF. Educative game on drugs for blind individuals: development and assessment. Rev Esc Enferm USP. [Internet] 2013 [cited 2015 nov 04]; 47: 930-6. Available from: http://www.scielo.br/pdf/reeusp/v47n4/ en_0080-6234-reeusp-47-4-0930.pdf

13. Andrade LZC, Freitas DT, Holanda GF, Silva VM, Lopes MVO, Araújo TL. Desenvolvimento e validação de jogo educativo: medida da pressão arterial. Rev Enferm. UERJ. [Internet] 2012 [cited 2015 nov 04]; 20:323-7. Available from: http://www. facenf.uerj.br/v20n3/v20n3a07.pdf

14. Sales MB, Mazzali BR, Amaral MA, Rocha RGO, Brito R. Inclusão digital de pessoas idosas: relato de experiências de utilização de software educativo. Rev Kairós Gerontol [Internet] 2014 [cited 2015 nov 04]; 17:63-81. Available from: http://revistas.pucsp.br/ index.php/kairos/article/view/23457/16848

15. Camacho ACLF, Abreu LTA, Leite BS, Mota ACO, Louredo DS, Silva RP. Validation of informative booklet about the elderly demented by nurses and nursing students: an observationaltransversal study. J Res Fundam Care Online [Internet] 2014[cited 2015 nov 04]; 6:8-16. Available from: http://www.seer.unirio.br/ index.php/cuidadofundamental/article/view/2421/pdf_1037

16. Barros EJL, Santos SSC, Gomes GC, Erdmann AL. Gerontotecnologia educativa voltada ao idoso estomizado à luz da complexidade. Rev Gaúcha Enferm. [Internet] 2012 [cited 2015 nov 04]; 33:95-101. Available from: http://www.scielo.br/ pdf/rgenf/v33n2/14.pdf

\section{Publish in International Archives of Medicine}

International Archives of Medicine is an open access journal publishing articles encompassing all aspects of medical science and clinical practice. IAM is considered a megajournal with independent sections on all areas of medicine. IAM is a really international journal with authors and board members from all around the world. The journal is widely indexed and classified Q2 in category Medicine. 